\title{
Influence of Molybdenum and Phosphorus Application on Yield, Yield Components, Carbohydrates and Protein Content of Mungbean
}

\author{
Junaid Ahmad ${ }^{1 *}$, Shazma Anwar', Anwar Ali Shad ${ }^{2}$, Sher Shah Souri', Bibi Amina ${ }^{3}$, Wajia Noor ${ }^{4}$, \\ Abidullah ${ }^{1}$ and Muhammad Adil ${ }^{1}$
}

${ }^{1}$ Department of Agronomy, The University of Agriculture, Peshawar, Khyber Pakhtunkbwa, Pakistan; ${ }^{2}$ Department of Agricultural Chemistry, The University of Agriculture Peshawar, Khyber Pakbtunkbwa, Pakistan; ${ }^{3}$ Institute of Biotechnology and Genetic Engineering, The University of Agriculture Peshawar Khyber Pakbtunkbwa, Pakistan; ${ }^{4}$ Department of Botany, Sardar Bahadur Khan Women's University Quetta, Pakistan.

Abstract | Pulses constitute an integral part of Pakistani diet and an important source of protein for a vast majority of the country and an important place in order to mitigate the protein requirements of increasing population. Mungbean has more protein contents and better digestibility than any other pulse crop. A field study was carried out at Agronomy Research Farm, The University of Agriculture, Peshawar in summer season 2018 with objectives to find out impact of molybdenum $\left(0,0.5,1.5\right.$ and $\left.2.5 \mathrm{~kg} \mathrm{ha}^{-1}\right)$ and phosphorus $\left(0,30,60\right.$ and $\left.90 \mathrm{~kg} \mathrm{ha}^{-1}\right)$ application on performance of mungbean. The trial was presented in randomized complete block design having three replicates. For molybdenum and phosphorus source, sodium molybdate and single super phosphate was used. The findings of trial indicated that molybdenum applied with $1.5 \mathrm{~kg}$ $\mathrm{ha}^{-1}$ to mungbean crop significantly improved pods plant ${ }^{-1}(29)$, seeds $\operatorname{pod}^{-1}(11)$, thousand seeds mass $(38 \mathrm{~g})$, biological and grain production (2960 and $\left.777 \mathrm{~kg} \mathrm{ha}^{-1}\right)$ while highest nodules plant ${ }^{-1}$ (26), plant height (79 $\mathrm{cm})$, protein $(21.70 \%)$, carbohydrates $(60.53 \%)$ and seed $\mathrm{N}$ content $(3.76)$ was recorded with molybdenum applied at rate of $2.5 \mathrm{~kg} \mathrm{ha}^{-1}$. Similarly in case of phosphorus application at rate of $60 \mathrm{~kg} \mathrm{ha} \mathrm{h}^{-1}$ recorded maximum pods (30), seed pod $^{-1}(11)$, thousand seed weightage $(40 \mathrm{~g})$, biological and grain production (3017, $\left.816 \mathrm{~kg} \mathrm{ha}^{-1}\right)$. Whereas phosphorus applied at rate $90 \mathrm{~kg} \mathrm{ha}^{-1}$ produced plants taller $(81 \mathrm{~cm})$, nodules plant ${ }^{-1}$ (22), protein (22.35\%), carbohydrates (61.11\%) and seed N content (3.60\%). Considering Mo x P, interactive effect was found significant for pods plant ${ }^{-1}$, protein, carbohydrates and seed $\mathrm{N}$ content of mungbean crop. On the basis of experimental consequences, it is clinched that mungbean crop with application of molybdenum and phosphorus at rate of 1.5 and $60 \mathrm{~kg} \mathrm{ha}^{-1}$ boosted yield and yield attributes and thus recommended for higher productivity in agro ecological zone of study area.

Received | January 18, 2021; Accepted | February 11, 2022; Published | February 24, 2022

*Correspondence | Junaid Ahmad, Department of Agronomy, The University of Agriculture, Peshawar, Khyber Pakhtunkhwa, Pakistan; Email: Junaid.agri@aup.edu.pk

Citation | Ahmad, J., S. Anwar, A.A. Shad, S.S. Souri, B. Amina, W. Noor, Abidullah and M. Adil. 2022. Influence of molybdenum and phosphorus application on yield, yield components, carbohydrates and protein content of mungbean. Pakistan Journal of Agricultural Research, 35(1): 93-104.

DOI | https://dx.doi.org/10.17582/journal.pjar/2022/35.1.93.104

Keywords | Protein, Carbohydrates, Seed nitrogen, Nodules, Grain yield

\section{Introduction}

$\mathrm{P}$ ulses have an important place in order to mitigate the protein requirements of increasing population of country. Mungbean (Vigna radiata L) belong to family leguminacea, also known as green bean. Mungbean is an essential in legumes ranked as the second most drought resistant crop after soybean. 
Mungbean has much proteins in its seeds and a good digestibility than other legumes. Mungbean have 51 to $60 \%$ carbohydrates, 20 to $25 \%$ protein and $3 \%$ other vitamins. The residue of green gram is used for animals and enhances fertility status of soil (Asaduzzaman, 2008). A balance fertilization of micro and macro nutrients is very important for high yield and high quality products (Sawan et al., 2008). Despite of its importance mungbean crop still got little attention in our country Pakistan and yet a lot of progress need to do for improving the quality and quantity of mungbean crop.

Phosphorous is an important nutrient for growth and development of any crop (Abdullah, 2000). It plays a major role in energy transfer, stimulation of early growth and development, fruiting and seed formation (Osadeke, 2005; Agbede, 2009). Phosphorous is recognized as one of the utmost limiting nutrient in crop production in tropical soil (Osadeke, 2005). Phosphorous required by seeds of many plants for enhancing the formation of seeds, metabolism regulations, blooming and protein synthesis and also an essential part of phospholipids and nucleic acid (Iqbal and Chuhan, 2003). Phosphorus applied in pulses plants are reported for improving dry matter production, enhancing root growth and formation of nodules in many legumes (Schulze et al., 2006). Phosphorus application also improved soil properties and nitrogen absorption which is necessary for all energy process in nodules formation and further growth and development of the plant (Anetor and Aknirinde, 2006). Amount of phosphorus present in many seeds and fruits are due to early crop maturity with phosphorus application, helps in seed formation and also in disease prevention (Raboy, 2003). The problem with $\mathrm{P}$ fertilization in these soils is its high fixation, thereby making applied $\mathrm{P}$ unavailable to crops. High $\mathrm{P}$ fixation has been reported in these soils (Henry and Smith, 2002). It also predicts the amount of fertilizer $\mathrm{P}$ required by crops. According to Warren (2002), immediate source of $\mathrm{P}$ taken up by plants is that in the soil solution which is itself supplied from the soil, rather than by direct transfer of $\mathrm{P}$ from the solid phase of the soils to the roots. A simple empirical approach was suggested by Tahir et al. (2014) that enough fertilizer $\mathrm{P}$ should be added to raise the concentration of phosphate in solution to an initial value adequate for maximum yield in a field experiment. Mung bean has considerable response to phosphorous as it highly responsive to words fertilizers. For plant growth in tropics phosphorous is one of the most limiting factors and it has been absorbed in tropical soil that production of common bean is limited by over $50 \%$ due to phosphate deficiency (Naeem et al., 2000).

Molybdenum is one of the most recognized nutrient elements considered to be essential for the growth of plant. Insecurity of food in current scenario increasing day by day due to different drought stresses induced by changing climate, particularly in regions of tropical and sub-tropical. Food legumes are a best and comparatively inexpensive sources for proteins, carbohydrates and other minerals (Paricha et al., 2008). Molybdenum, belong a constituent of nitrate reductase and nitrogen enzymes, is associated with ammonia reduction by nitrogen faction and its deficiency adversely affects growth and yield of mung bean (Fageria et al.,2015; Paricha et al.,2008; Velu and Savithri, 2008). An applied molybdenum has been identified for increasing in nodulation, growth and grains productivity of various legumes (Choudhary and Das, 2006). Molybdenum works an important role in various biochemical process in plants and is a fundamental component of nitrogenase activities (Fageria et al., 2011). Many enzymatic processes which catalyzes the reduction of atmospheric nitrogen in to ammonia and a cofactor in nitrogen reductase (Singh et al., 2014). Due to the important part of molybdenum in the mechanism associated with regulation of nitrogen fixation in legumes. Molybdenum supplementation has increase $\mathrm{N}$ accumulation and grain in common beans as reported by several authors (Awomi et al., 2012). The role of molybdenum in plants is discussed, focusing on its current constraints in some agricultural situations and where increased molybdenum nutrition may aid in agricultural plant development and yields. Keeping in view noteworthiness of molybdenum and phosphorus on productivity of mungbean, the current experiment was planned to explore the best combination of molybdenum and phosphorus fertilizer for improving productivity and nodules formation of mungbean.

\section{Materials and Methods}

A field study was assessed at Agronomy Research Farm, Agriculture University Peshawar in kharif season 2018. Sowing was done at second July whereas harvesting was performed at $25^{\text {th }}$ September. The study was carried out in randomized complete block 
design and replicated thrice. $3 \mathrm{~m} \times 1.8 \mathrm{~m}$ plots with 6 rows in each plot having R-R distance $30 \mathrm{~cm}$ and $\mathrm{P}-\mathrm{P}$ distance $10 \mathrm{~cm}$ was maintained. Various doses of molybdenum and phosphorus was used during the trial. Molybdenum levels were (Control, 0.5, 1.5 and $2.5 \mathrm{~kg} \mathrm{ha}^{-1}$ ) while phosphorus levels were (Control, 30 , 60 and $90 \mathrm{~kg} \mathrm{ha}^{-1}$ ). Variety Ramzan-92 of mungbean was sown at rate of $25 \mathrm{~kg} \mathrm{ha}^{-1}$ during experiment with the help of seed drill. Initial dose of nitrogen was used $25 \mathrm{~kg} \mathrm{ha}^{-1}$. Mentioned phosphorous levels were used at the time of sowing. In agronomic practices, Weeding was done twenty days after sowing. Thinning was performed twice, firs twenty days after sowing of crop and second was before flowering. In whole season three irrigations were applied to field, $1^{\text {st }}$ irrigation was applied after seven days sowing of crop, second irrigation before flowering stage and third was done at pods filling stage.

\section{Climate of the site}

The-climatic condition-of-the site area-is-semiarid. The experimental site is located at $34.01^{\circ}-\mathrm{N}$ latitude and $71.35^{\circ}$-E longitude, at an altitude of $350 \mathrm{~m}$ above sea-level in Peshawar-valley. Soil of the experimental site is clay/silt-loam with low level of organicmatter-(0.87-\%), phosphorus 6.57- $\mathrm{mgkg}^{-1}$, potassium $121-\mathrm{mgkg}^{-1}, \mathrm{pH} 7.78$ while nature of soil is calcareous (Amanullah et al., 2009). Other soil physiochemical properties were derived and given in Table 1.

Table 1: Pre-sowing soil physico-chemical properties (0$30 \mathrm{~cm}$ depth).

$\begin{array}{lll}\text { Soil properties } & \text { Unit } & \text { Value } \\ \text { Clay } & \% & 12.5 \\ \text { Silt } & \% & 49.7 \\ \text { Sand } & \% & 36.8 \\ \text { Textural class } & - & \text { Silt loam } \\ \mathrm{pH} & - & 7.78 \\ \mathrm{EC} & \mathrm{d} \mathrm{S} \mathrm{m}^{-1} & 0.16 \\ \text { Organic matter } & \% & 0.83 \\ \text { Total nitrogen } & \% & 0.067 \\ \text { Phosphorus } & \mathrm{mg} \mathrm{kg}{ }^{-1} & 2.33 \\ \text { Potassium } & \mathrm{mg} \mathrm{kg}^{-1} & 106.3\end{array}$

\section{Molydenum and Phosphorus application}

Sodium molybdate and single super phosphate was used as source for molybdenum and phosphorus. For even distribution of molybdenum levels in field, sodium molybdate was mixed with soil (1g sodium molybdate with $5 \mathrm{~g}$ of soil) and then applied through band placement on single side of each row at sowing time. While all the mentioned phosphorous levels were applied at the time of sowing.

\section{Date studied}

Nodule numbers plant ${ }^{-1}$ was collected from ten different plants selected haphazardly in each plot at before flowering stage. Data was then averaged. Height of plants was determined by ten plants randomly in each treatment and taken its total height through measuring rod and averaged all the measured data. Randomly selection was done from ten different plants for data of pods number plant ${ }^{-1}$ in every treatment and data was then averaged. Seeds number per pod was calculated manually by seeds counted in selected ten pods randomly and data was then averaged. For thousand seed weight from seed production of each plot, one thousand seeds were taken and weighed with weighing balance and then averaged. For biological yield central four rows were harvested in every treatment manually, bundled and sundried for ten days. After sun dryness all bundles were weighed and converted the outcomes into $\mathrm{kg}$ $\mathrm{ha}^{-1}$. For grain yield central rows harvested manually with help of sickle in every treatment, bundled and sundried in sun for ten days. The samples were threshed and weighed through balance. The data was renewed in to $\mathrm{kg} \mathrm{ha}^{-1}$. Seed total $\mathrm{N}$ were determined via Kjeldahl process (Bremmer and Mulvaney, 1996). Sample seeds was grinded with sieved from 0.2 $\mathrm{mm}$ sieve for getting the clear and fine powder for nitrogen determination contents. The sample seed powder of $0.2 \mathrm{~g}$ in the presence of digestion mixture and digested with concentrated $\mathrm{H}_{2} \mathrm{SO}_{4}(3 \mathrm{ml})$ at temperature of $350^{\circ} \mathrm{C}$ till the light greenish color of the samples appeared. The mixture was diluted upon cooling. $20 \mathrm{ml}$ of the diluted digested was distilled with $40 \% \mathrm{NaOH}$ solution and mixed indicator, and then titrated against $\mathrm{HCl}$ solutions, and calculation was made after adjusting for blank reading. Protein and carbohydrates analysis were done according to the standard method as explained by (AOAC, 1990).

\section{Statistical analysis}

Statistically all the data obtained during experiment were analyzed with method used of analysis of variance for randomized complete block design. While all means were obtained on LSD test at 0.05 probability (Jan et al., 2009). 
Results and Discussion

\section{Nodules plant ${ }^{-1}$}

Observations of variance indicates there was a substantial impact of molybdenum and phosphorus usage on nodules plant ${ }^{-1}$ of mungbean, while the interaction among molybdenum and phosphorus had non-significantly influenced nodules plant ${ }^{-1}$ (Table 2). Average data showed that molybdenum applied at $2.5 \mathrm{~kg} \mathrm{ha}^{-1}$ give most (26) of nodules, while less (14) nodules was noted in check. In case of the application of phosphorus, a greater (22) nodules numbers were verified with $90 \mathrm{~kg} \mathrm{ha} \mathrm{ha}^{-1}$ phosphorus application, however a smaller number of (17) nodules were observed in control plots. The number of nodules plant $^{-1}$ is central parameter in study, as it was the key measure for biological nitrogen fixation. Analysis of the nodules exposed that the nodules number were impacted knowingly by molybdenum and phosphorus. Results revealed that molybdenum applied at higher doses $\left(2.5 \mathrm{~kg} \mathrm{ha}^{-1}\right)$ formed a greater nodules number, while less nodules were noted in no application plots. An increasing number of nodules could be due to the circumstance that molybdenum is a critical essential for reductase of nitrate and nitrogenous enzymes that helps reduce inorganic nitrate and ultimately produce more nodules (Ryan et al., 2012). Mo stimulated the activities of rhizobium and, in turn the nodules number, which improved the absorption of nitrogen by the plants. Our consequences are also in link to the findings of Williams and Silva (2002) conveyed that molybdenum application resulted significantly in the formation of a maximum nodules number. A lined growth in nodules number was achieved with enhancement in phosphorus. More nodules number noted in plots with more doses of $\mathrm{P},(90 \mathrm{~kg})$ was counted. The increase in nodules with rise in the doses of $\mathrm{P}$ could be owing to the amount of phosphorus to the roots of the plant at numerous stages of growth, particularly at the period of nodule development (Hussain et al., 2012). Alike conclusions were also observed by Khan et al. (2017) and Muhammad et al. (2005), they described that rise in $\mathrm{P}$ doses improved number of nodules numbers.

\section{Plant height $(\mathrm{cm})$}

Analysis related to the height of the plant indicated that the treatments with molybdenum and phosphorus had expressively impact the height of the mungbean plants, interaction was recorded nonsignificant (Table 2). Average data displays that molybdenum at $2.5 \mathrm{~kg} \mathrm{ha}^{-1}$ results in higher plant $(79 \mathrm{~cm})$ while shorter plants $(69 \mathrm{~cm})$ were shown in control. Comparing phosphorus levels, taller plants of $(81 \mathrm{~cm})$ were measured through phosphorus applied at rate of $90 \mathrm{~kg} \mathrm{ha}^{-1}$ usage, though the shorter plants of $(69 \mathrm{~cm})$ was noted in no phosphorous applications plots. Healthy and taller plant are contributing for good crop stand and productivity. It can have a straight impact on the biological and yield of seeds. Investigation of the data exposed that the height of the mungbean is impacted knowingly by application of molybdenum and phosphorus. Height of the plant increases as the molybdenum rate increased up to 2.5 $\mathrm{kg} \mathrm{ha} \mathrm{h}^{-1}$. Our discoveries are in contract with Bhuiyan et al. (2008) they measured taller plants of mungbean with an increasing rate of molybdenum. Aghatiso and Tayo (2004) described same consequences that molybdenum application improved significantly height of the soybean plant compared to the control. In the case of phosphorus, a linear increase was observed as phosphorus levels increased. This increase could be because of the fact that phosphorus acts a critical character in root development and is vital for respiration, energy synthesis and plant photosynthesis, which resulted in improved growth (Ali et al., 2014). Our consequences are in confirmation by Jabbar et al. (2012) found a tall height of the mungbean crop plant with an increase in phosphorus doses.

Table 2: Showed nodules plant ${ }^{-1}$, plant height, pods plant ${ }^{-1}$, seedspod ${ }^{-1}$ and thousand seeds weight of mungbean as influenced by molybdenum and phosphorus application.

\begin{tabular}{|c|c|c|c|c|c|}
\hline $\begin{array}{l}\text { Phospho- } \\
\text { rus (kg } \\
\left.\text { ha }^{-1}\right)\end{array}$ & $\begin{array}{l}\text { Nodules } \\
\text { plant }^{-1}\end{array}$ & $\begin{array}{l}\text { Plant } \\
\text { height } \\
\text { (cm) }\end{array}$ & $\begin{array}{l}\text { Pods } \\
\text { plant }^{-1}\end{array}$ & $\begin{array}{l}\text { Seeds } \\
\operatorname{pod}^{-1}\end{array}$ & $\begin{array}{l}\text { Thousand } \\
\text { seed weight } \\
\text { (g) }\end{array}$ \\
\hline 0 & $17 \mathrm{c}$ & $69 c$ & $24 \mathrm{~d}$ & $9 c$ & $34 \mathrm{c}$ \\
\hline 30 & $19 \mathrm{~b}$ & $73 \mathrm{~b}$ & $26 \mathrm{c}$ & $9 c$ & $36 \mathrm{~b}$ \\
\hline 60 & $20 \mathrm{~b}$ & $75 \mathrm{~b}$ & $30 \mathrm{a}$ & 11 & $40 \mathrm{a}$ \\
\hline 90 & $22 \mathrm{a}$ & $81 \mathrm{a}$ & $27 \mathrm{~b}$ & $10 \mathrm{~b}$ & $37 \mathrm{~b}$ \\
\hline $\operatorname{LSD}_{(0.05)}$ & 1.8 & 3.53 & 1.3 & 0.49 & 1.6 \\
\hline \multicolumn{6}{|c|}{ Molybdenum (kg ha $\left.{ }^{-1}\right)$} \\
\hline 0 & $14 \mathrm{~d}$ & $69 \mathrm{~b}$ & $25 \mathrm{c}$ & $8 \mathrm{~d}$ & $35 \mathrm{a}$ \\
\hline 0.5 & $17 \mathrm{c}$ & $72 \mathrm{~b}$ & $26 \mathrm{~b}$ & $9 c$ & $37 a b$ \\
\hline 1.5 & $21 \mathrm{~b}$ & $76 \mathrm{a}$ & $29 \mathrm{a}$ & 11 & $38 \mathrm{a}$ \\
\hline 2.5 & $26 \mathrm{a}$ & $79 \mathrm{a}$ & $28 \mathrm{a}$ & $10 \mathrm{~b}$ & $37 \mathrm{a}$ \\
\hline $\operatorname{LSD}_{(0.05)}$ & 1.8 & 3.53 & 1.3 & 0.49 & 1.6 \\
\hline
\end{tabular}

\section{Pods plant ${ }^{-1}$}

Data analysis showed that levels of molybdenum and phosphorus had significant impact on pods umber 
plant $^{-1}$ (Table 2) while their interaction was also significantly influenced pods plant $^{-1}$ of mungbean (Figure 1). Mean values represented that plants practiced with molybdenum at $1.5 \mathrm{~kg} \mathrm{ha}^{-1}$ results more (29) pod numbers that are statistically at par with usage of $2.5 \mathrm{~kg}$ Mo. Comparing phosphorus levels, more pods (30) plant $^{-1}$ were found in plants that received $60 \mathrm{~kg}$ of phosphorus, while less pods (24) were found in control treatments. Considering the interactive impact of molybdenum and phosphorus, a greater pods numbers plant ${ }^{-1}$ (32) found in those treatments where molybdenum was used at lower rate $(1.5 \mathrm{~kg}$ ha $\left.{ }^{1}\right)$ while $\mathrm{P}$ was used higher doses $\left(60 \mathrm{~kg} \mathrm{ha}^{-1}\right)$. Pods plant $^{-1}$ is a main aspect in defining the mungbean yield performance. Several rates of molybdenum, phosphorus and their interactive impact showed a significant outcome on pod numbers of mungbean. Recent study investigated that fertilized treatments with $\left(1.5 \mathrm{~kg} \mathrm{ha}^{-1}\right)$ significantly provided a greater pods plant $^{-1}$, which are statistically similar with $(2.5 \mathrm{~kg} \mathrm{Mo})$, whereas lesser number of pods achieved in control treatments. Possibility could be because to efficient use of molybdenum applied at the time of planting, which regulated effective nodulation, nitrogen fixation and the positive effect on the performance attributes of mungbean (Awomi et al., 2012). These consequences are in close complement with conclusions of Padhi et al. (2018), they found utilization of molybdenum resulted in maximum performance and performance related attributes in mungbean. While in the occasion of phosphorus application, rise in phosphorus doses up to $60 \mathrm{~kg} \mathrm{ha}^{-1}$ caused in greater pods followed by $\mathrm{P}$ at $90 \mathrm{~kg} \mathrm{ha}{ }^{-1}$, and less pods observed in control treatments. Rise in the important attributes may be because of holding of extra nodules that actually provide enough nitrogen for vegetative growth (Ali et al., 2010). These achievements were accepted by Khan et al. (2017) who described that the pods numbers improved by enhancement in phosphorus. Ali et al. (2014) also explained that applied phosphorus of $65 \mathrm{~kg}$ $\mathrm{ha}^{-1}$ improved pointedly pods numbers of mungbean.

\section{Number of seeds pod ${ }^{-1}$}

Analysis related to mungbean seeds per pod as impacted with different doses of molybdenum and phosphorus is existed in Table 2. A significant influence was perceived in seeds number pod $^{-1}$ with Mo and phosphorus, but collaboration impact was established not-significant. Molybdenum applied at $1.5 \mathrm{~kg} \mathrm{ha}{ }^{-1}$ resulted more (11) seeds per pod, while fewer (8) seed per pod were noted in check plots.
Comparing phosphorus levels, more seeds (11) pod $^{-1}$ seeds in those plots was observed, who receive $60 \mathrm{~kg}$ $\mathrm{ha}^{-1}$ of $\mathrm{P}$, following $90 \mathrm{~kg} \mathrm{ha}{ }^{-1}$, while the less (9) pod $^{-1}$ seeds noted in control plots statistically at similarity with $30 \mathrm{~kg} \mathrm{P} \mathrm{ha}{ }^{-1}$. Statistics analysis exposed that seeds pod $^{-1}$ were influenced meaningfully by Mo and phosphorus. Fertilized plots with $1.5 \mathrm{~kg} \mathrm{ha}^{-1}$ Mo gave the maximum seeds pod ${ }^{-1}$ followed by $2.5 \mathrm{~kg} \mathrm{ha}^{-1}$, and lower seeds noted in control. This increasing rate of seeds pod ${ }^{-1}$ with molybdenum application could be due to the fact that molybdenum improved the fixation capacity of $\mathrm{N}$, which resulted in maximum use of chlorophyll and photosynthesis and in higher yield and bean yield attributes. mungo (Deo and Kothari, 2002). These findings are in promise with Tahir et al. (2014); Singh and Pareek (2003) they founded Mo gave knowingly more yield characteristics of black gram. The use of phosphorus also responds positively to seeds pod ${ }^{-1}$. Plots taking $60 \mathrm{~kg}$ of $\mathrm{P}$ showed the maximum seeds number followed by $90 \mathrm{~kg}$ of $\mathrm{P}$ relate to treatments where no $\mathrm{P}$ was practiced. The reason for these outcomes could be that phosphorus increased storage substances, photosynthesis, carbohydrate transfer, fruit color and roughness (Nikfarjam and Aminpanah, 2015). Khan et al. (2017) and Kumar et al. (2012) noted that utilization of phosphorus at greater amounts provided the maximum grains pod-1 compared to lower doses of phosphorus.

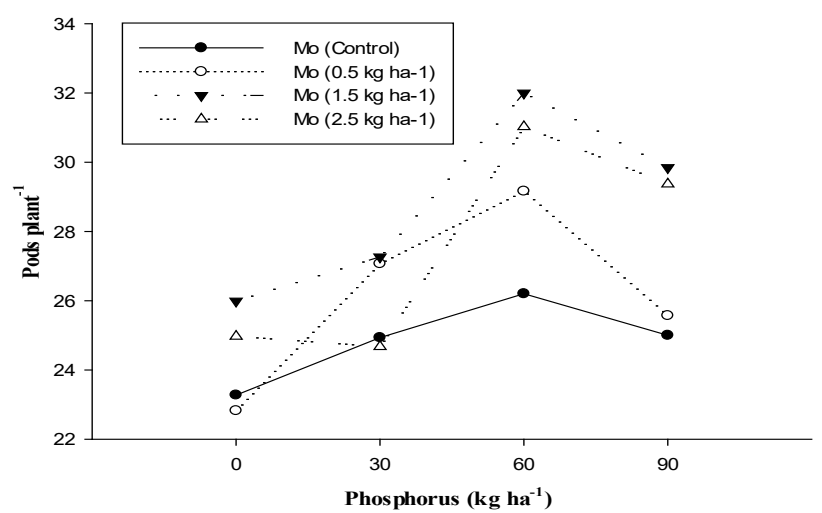

Figure 1: Interactive effect of molybdenum and phosphorus on pods plant ${ }^{-1}$ of mungbean.

\section{Thousand seeds weight (g)}

Application of molybdenum and phosphorus on thousand seeds weight of mungbean is presented in Table 2. When analyzing the data statistically and perceived that the practicing molybdenum and phosphorus significantly influenced the weight of one thousand mungbean seeds. However, the relations among molybdenum and phosphorus were noted non-significant. The heaviest seeds $(38 \mathrm{~g})$ were 
produced by plants that received molybdenum at 1.5 $\mathrm{kg} \mathrm{ha}{ }^{-1}$ associated to lighter seeds (35 g) recorded in control plots. Considering the phosphorus levels, greater value for the weight of one thousand seeds (40 g) observed from those mungbean plants which received phosphorus at $60 \mathrm{~kg}$ traced by phosphorus at $90 \mathrm{~kg} \mathrm{ha}{ }^{-1}$, although the plants of control plots give less seed weight $(34 \mathrm{~g})$. Weight of seed is majorly contributor for final production. The weight of thousand mungbean seeds affected substantially with levels of molybdenum and $\mathrm{P}$, while $\mathrm{Mo} \times \mathrm{P}$ was found not significant. Heavier seeds were recorded from fertilized plots with $1.5 \mathrm{Mo} \mathrm{kg} \mathrm{ha}^{-1}$ tracked by Mo 2.5 $\mathrm{kg} \mathrm{ha}^{-1}$, whereas lighter seeds were founded in control treatments. This rise in seeds weight of mungbean crop could be owing to intensification in the phosphorus content of seed because molybdenum is elaborated in several physiological methods of plants (Yadav and Singh, 2017). Parallel consequences were also conveyed by Kulsoom et al. (2007) they explained seed weight increases with the application of molybdenum in the case of mungbean and black gram. Plots usage with a phosphorus level at a rate of $60 \mathrm{~kg}$ of haformed heavier seeds, whereas the lower weight of seeds was recorded in no fertilized plots. This result might be due to that phosphorus improves the growth of the plant and produces more assimilates that for its development are transferred to the seed (Malik et al., 2015). Our findings also agree with Ahmed et al. (2018) they achieved a greater weight of seeds in plots attaining $\mathrm{P}$ at $60 \mathrm{~kg} \mathrm{ha}^{-1}$. Ahmed et al. (2018) explained same findings by observing that rising in doses of $\mathrm{P}$ up to $60 \mathrm{~kg} \mathrm{ha}^{-1}$ resulted more seed weight.

\section{Biological yield $\left(\mathrm{kg} \mathrm{ha}^{-1}\right)$}

Analysis for the data of biological production of mungbean impacted by diverse levels of molybdenum and phosphorus are existed in Table 3. Analysis exposed that molybdenum and phosphorus addition expressively influenced the biological yield of mungbean crop, while their collaboration had notsignificant impact on biological yield. The maximum biological yield (2960 kg ha-1) of mungbean was produced by utilization of molybdenum at $1.5 \mathrm{~kg}$ $\mathrm{ha}^{-1}$, similar to molybdenum at rate of $2.5 \mathrm{~kg} \mathrm{ha}$ 1. Similarly, in case of phosphorus, higher biomass production $(3017 \mathrm{~kg}$ ) was observed in treatments of phosphorus was practiced at $60 \mathrm{~kg} \mathrm{ha}^{-1}$ traced by phosphorous at $90 \mathrm{~kg} \mathrm{ha}^{-1}$ produced $\left(2882 \mathrm{~kg} \mathrm{ha}^{-1}\right)$ however less biomass yield $\left(2534 \mathrm{~kg} \mathrm{ha}^{-1}\right)$ was noted in check plots. The different levels of application of molybdenum and phosphorus in mungbean have a significant impact on mungbean biomass production, while the mutual effect among Mo x $\mathrm{P}$ was noted not-significant. The utilization of molybdenum (1.5 $\mathrm{kg} \mathrm{ha}^{-1}$ ) made the heavy biomass, which is statistically alike with $2.5 \mathrm{~kg}$ Mo ha-1, while the less yield was observed in control treatments. The enhance in the biological production of mungbean with molybdenum could be because of the maximum germination rate and the stable growing design of the plant that led to the total production of dry matter and gives a positive response to the maximum seed yield Kulsum et al. (2007). These achievements are with support of Tahir et al. (2014) who confirmed Mo improved the production of attributes related to the growing and productivity of mungbean. Considering phosphorus levels, the more biomass production with utilizing 60 $\mathrm{kg}$ of $\mathrm{P} \mathrm{ha}{ }^{-1}$, following with $90 \mathrm{~kg}$ of $\mathrm{P} \mathrm{ha}^{-1}$, while the minimum biological yield calculated from control. The reason for this rise in yield could be that phosphorus supports the crop to create more seeds and further propagative fragments that eventually contribute to other components of yield and biological performance (Rahman et al., 2008). Our consequences promised with Khan et al. (2017) they conveyed more biological performance where the highest dose of phosphorus was applied. Rani et al. (2016) also noted that phosphorus application caused in greater root growth and biological performance.

Table 3: Showed grain yield, biological yield, protein, carbobydrates and seeds $N$ content of mungbean as influenced by molybdenum and phosphorus application.

\begin{tabular}{|c|c|c|c|c|c|}
\hline $\begin{array}{l}\text { Phos- } \\
\text { phorus } \\
\left(\mathrm{kg} \mathrm{ha}^{-1}\right)\end{array}$ & $\begin{array}{l}\text { Grain } \\
\text { yield (kg } \\
\left.\text { ha }^{-1}\right)\end{array}$ & $\begin{array}{l}\text { Biological } \\
\text { yield (kg } \\
\text { ha-1) }^{-1}\end{array}$ & $\begin{array}{l}\text { Protein } \\
\text { (\%) }\end{array}$ & $\begin{array}{l}\text { Carbo- } \\
\text { hydrates } \\
(\%)\end{array}$ & $\begin{array}{l}\text { Seeds N } \\
\text { content } \\
(\%)\end{array}$ \\
\hline 0 & $562 \mathrm{c}$ & $2534 \mathrm{c}$ & 19.81 & 56.42 & $2.84 \mathrm{~d}$ \\
\hline 30 & $606 \mathrm{bc}$ & $2736 \mathrm{bc}$ & 20.57 & 57.50 & $3.12 \mathrm{c}$ \\
\hline 60 & 816 a & 3017 a & 21.75 & 58.78 & $3.35 \mathrm{~b}$ \\
\hline 90 & $669 \mathrm{~b}$ & $2882 \mathrm{ab}$ & 23.03 & 61.11 & $3.60 \mathrm{a}$ \\
\hline $\operatorname{LSD}_{(0.05)}$ & 84.65 & 222.4 & 0.44 & 0.61 & 0.16 \\
\hline \multicolumn{6}{|c|}{ Molybdenum (kg ha $\left.{ }^{-1}\right)$} \\
\hline 0 & $537 c$ & $2575 \mathrm{~b}$ & 20.22 & 57.12 & $2.62 \mathrm{~d}$ \\
\hline 0.5 & $630 \mathrm{~b}$ & $2753 \mathrm{ab}$ & 20.89 & 57.37 & $2.95 \mathrm{c}$ \\
\hline 1.5 & $777 \mathrm{a}$ & $2960 \mathrm{a}$ & 21.70 & 58.79 & $3.59 \mathrm{~b}$ \\
\hline 2.5 & $707 \mathrm{ab}$ & $2880 \mathrm{a}$ & 22.35 & 60.53 & $3.76 \mathrm{a}$ \\
\hline $\operatorname{LSD}_{(0.05)}$ & 84.65 & 222.4 & 0.44 & 0.61 & 0.16 \\
\hline
\end{tabular}

Seeds yield $\left(\mathrm{kg} \mathrm{ha}^{-1}\right)$

Data on seeds production as impacted with 
molybdenum and phosphorus doses are existed in Table 3. Investigations confirmed that molybdenum and phosphorus substantially influenced seed production of mungbean, whereas the interactive impact of both elements exhibit non significantly. Mean data values exposed that molybdenum applied at $1.5 \mathrm{~kg} \mathrm{ha}^{-1}$ created higher yield of seeds $(777 \mathrm{~kg} \mathrm{ha}$ 1) followed by molybdenum at $2.5 \mathrm{~kg} \mathrm{ha}^{-1}$. In situation of phosphorus doses, a higher seed yield of mungbean $\left(816 \mathrm{~kg} \mathrm{ha}^{-1}\right)$ in treatments of phosphorus used at 60 $\mathrm{kg}$ traced by $90 \mathrm{~kg} \mathrm{ha}^{-1}$ of phosphorus that produced $669 \mathrm{~kg} \mathrm{ha}^{-1}$ seed yield, though lower yield $(562 \mathrm{~kg} \mathrm{ha}$ $\left.{ }^{1}\right)$ was detected in check treatments. Seeds yield is a final production of every crop in study and based on several features. The present study indicated that seed yield varied significantly with different application treatments of molybdenum and phosphorus. The maximum seed yield was observed in those treatments gaining with $1.5 \mathrm{~kg}$ of $\mathrm{Mo} \mathrm{ha}^{-1}$ tracked by $2.5 \mathrm{~kg}$ of ha-1. This growth in yield of seed could be because of molybdenum that improved rhizobium activity, nitrogen fixation, vegetative growth and yield components in mungbean. Mo has a prominent role in the effectiveness of the nodules, which made the soil environment favorable for the absorption of other nutrients from the soil, promoted nitrogen fixation and played a positive role in flowering, pod formation and other performance attributes (Chattarjee and Bhandyopadhy, 2017). These consequences are in agreement with those conveyed by Pattanayak et al. (2000) who confirmed that the yield of mung bean grain increased with increasing molybdenum levels compared to the control. Similarly, in form P, more seed production of fertilized plots $60 \mathrm{~kg}$ of $\mathrm{P} \mathrm{ha}{ }^{-1}$ was achieved, tailed by fertilized treatments having $90 \mathrm{~kg}$ of $\mathrm{P}$, while seed yield lower was noted in the control plots. The reason for the increase in seed yield with higher phosphorus could be due to the development of the root, the greater absorption of nutrients and a greater accumulation of dry matter during the growth period and the translocation of more photosynthesis to the seed (Anwar et al., 2018; Ahmad et al., 2018). Phosphorus fertilizer helped the crop create extra seeds and other reproductive measures that eventually subsidised to yield (Rani et al., 2016). The consequences are also in line with Tariq et al. (2007) they showed a more seed production with higher doses of $\mathrm{P}$ to mungbean.

Seed $N$ content (\%)

Analysis of the data proposed that molybdenum, phosphorus and Mo x $\mathrm{P}$ influenced significantly the seeds $\mathrm{N}$ content (Table 3). A higher seeds $\mathrm{N}$ content $(3.76 \%)$ was recorded with a higher dose of molybdenum $\left(2.5 \mathrm{~kg} \mathrm{ha}^{-1}\right)$ traced by a molybdenum of $1.5 \mathrm{~kg} \mathrm{ha}^{-1}$, less seeds $\mathrm{N}$ was recorded (2.62\%) in control plots. In result of phosphorus, higher seed N (3.60\%) was observed with phosphorus usage at $90 \mathrm{~kg} \mathrm{ha}^{-1}$ traced by phosphorus at 60 $\mathrm{kg} \mathrm{ha}{ }^{-1}$, whereas minimum (2.84\%) was noted in control treatments. The interactive response of Mo x $\mathrm{P}$ displayed a progressive impact on the $\mathrm{N}$ amount of grain and increases with rising rates of phosphorus and molybdenum (Figure 2). The highest seed $\mathrm{N}(4.17 \%)$ was achieved from those plots fertilized with molybdenum at $2.5 \mathrm{~kg}$ ha-1 and $90 \mathrm{~kg}$ ha-1 P comparatively. Seeds nitrogen content was significantly influenced with molybdenum, phosphorus and Mo x P. Seeds $\mathrm{N}$ were positively improved with increasing levels of molybdenum. Treated plots with greater molybdenum dose of $(2.5$ $\mathrm{kg}$ ha-1) showed significantly higher $\mathrm{N}$ content. The possible reason for this might be that molybdenum application significantly enhanced nodules efficiency and activate rhizobium for higher fixation of nitrogen from atmosphere for the plant (Agatise and Tayo, 2004). These outcomes are relation to the discoveries of Nautiyal et al. (2005) they exposed grain $\mathrm{N}$ content was significantly ameliorated with more molybdenum doses. In case of phosphorus, grain $\mathrm{N}$ content was enlarged with growing levels of phosphorus. Higher seeds $\mathrm{N}$ content was recorded with maximum dose of phosphorus application, whereas seed nitrogen content was decreased with lower dose of phosphorus. Phosphorus as energy source had strong effect on chlorophyll content, photosynthesis and other metabolic activities to enhance grain $\mathrm{N}$ content (Alam et al., 2010). Hussain et al., (2012) conveyed $\mathrm{P}$ is crucially essential for many physiological functions of plants. Phosphorus application had significant response in the efficiency of root nodules, soil bacteria and play major role in biological nitrogen fixation (Jabbar and Saud, 2012)

\section{Protein content (\%)}

Analysis of the data indicated that protein content of mungbean crop had positively influenced with the combined application of phosphorus and molybdenum (Table 3) while the interaction among molybdenum and phosphorus have also positive impact on protein (\%) content of mungbean (Figure

3). Protein content of mungbean was observed 
higher with higher dose of phosphorus application. Phosphorus applied dose of $90 \mathrm{~kg} \mathrm{ha}^{-1}$ recorded more protein content i.e. $(23.03 \%)$ while in case of no dose of phosphorus applied observed less amount of protein content $\%$ i.e. (19.81\%). Mehboob et al. (2019) stated that protein $\%$ is increased with increasing dose of phosphorus application. This increasing trend might be due to the fact that Phosphorus is vital for development of new tissue and the transfer of the genetic information within the plant from one cell to another during cell formation. Similar results were correlated with investigations from Rani et al. (2016). Mehboob et al. (2019) and Gruhun et al. (2000) they stated that phosphorus application recorded enhancing in content of protein (\%) of mungbean. Similarly in case of molybdenum addition response with increasing trend to increasing levels of molybdenum. Molybdenum dose applied with the rate of $2.5 \mathrm{~kg} \mathrm{ha} \mathrm{h}^{-1}$ recorded higher trend of protein \% i.e. $(22.35 \%)$ followed by $(21.70 \%)$ with application rate of molybdenum at rate of $1.5 \mathrm{~kg} \mathrm{ha}{ }^{-1}$ while less amount of protein content (20.22\%) was observed with no molybdenum addition. It might be due to fact that molybdenum is essential for nitrogenase activities of most of biotic creatures containing plants also (Graham and Stangoulis, 2005). Normally, Mo is a vital micronutrient for bacteria and plants also (William and Silva, 2002). Meagher et al. (1991) conveyed the character of Mo in typical incorporation of nitrogen by plants is known, because molybdenum is a fundamental constituent of nitrate reductase and nitrogenase, which resist to the lessening of mineral nitrate and supports for fixative of $\mathrm{N} 2$ to NH3. Thus, molybdenum is the basic to nitrogen fixation and increasing the protein content of by legumes.

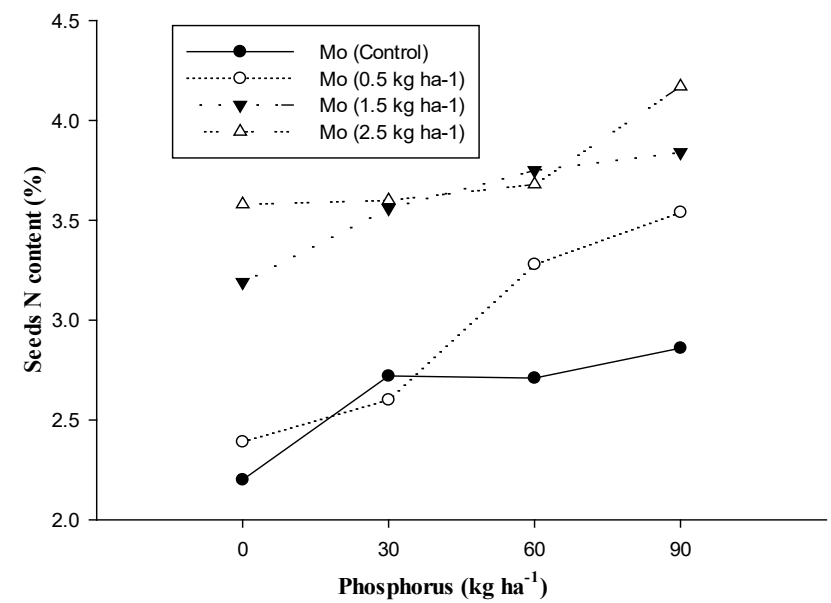

Figure 2: Interactive effect of molybdenum and phosphorus on seeds $N$ content (\%) of mungbean.

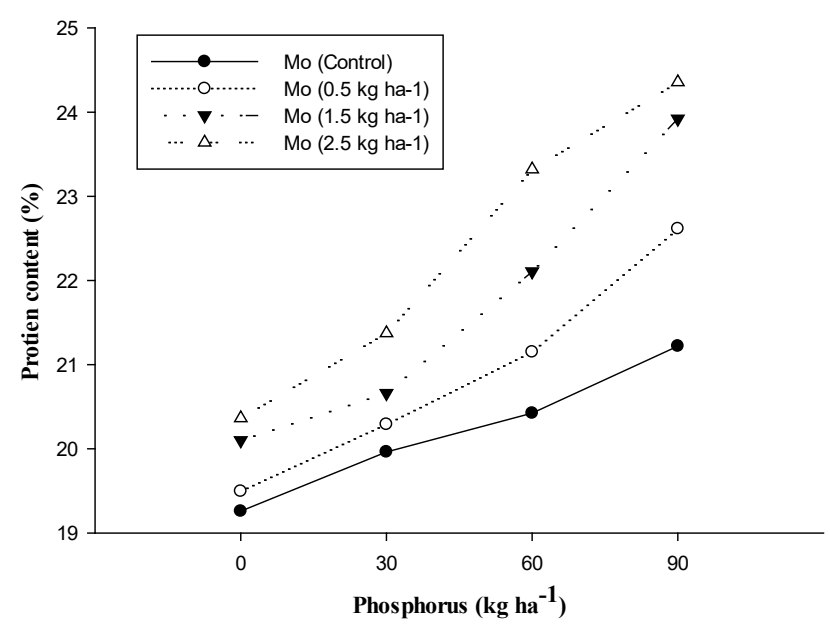

Figure 3: Interactive effect of molybdenum and phosphorus on Protein content (\%) of mungbean.

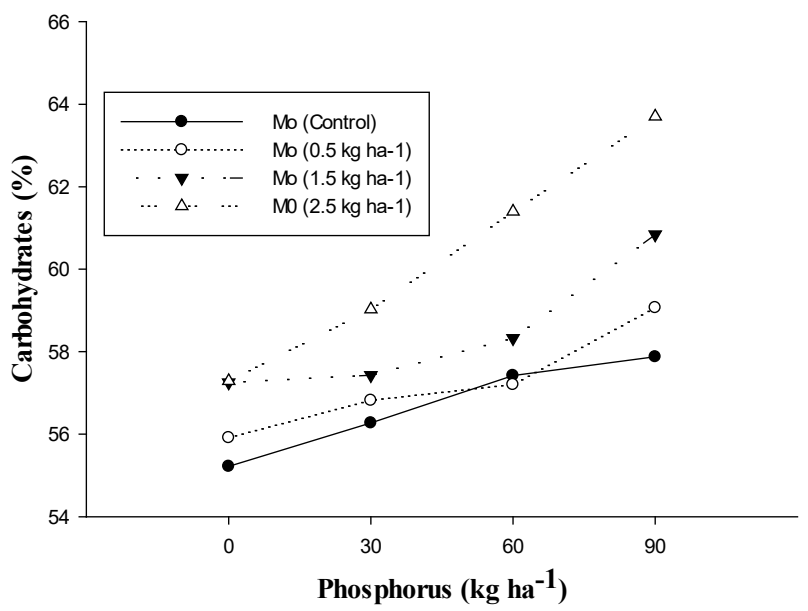

Figure 4: Interactive effect of molybdenum and phosphorus on Carbohydrates content (\%) of mungbean.

\section{Carbohydrates content (\%)}

Data regarding Carbohydrates content of mungbean as influenced by molybdenum and phosphorus application on mungbean crop presented in Table 3 . Analysis of variance indicated that both molybdenum and phosphorus and their combined application performed significantly positive response towards carbohydrates contents (\%) of mungbean crop (Figure 4). Molybdenum application at the rate of $2.5 \mathrm{~kg} \mathrm{ha}^{-1}$ recorded maximum carbohydrates contents $(60.53 \%)$ while less $(57.12 \%)$ in control treatments. While in case of phosphorus application carbohydrates contents were enhanced by phosphorus application at the rate of $90 \mathrm{~kg} \mathrm{ha}^{-1}$ recorded more $(61.11 \%)$ carbohydrates than control treatments (56.42\%). Improving carbohydrates contents by molybdenum and phosphorus application might be due to molybdenum enhance the nodulated efficiency of mungbean crop, with greater formation of more nodules in numbers it may be able to fix more atmospheric nitrogen as 
in their roots and forward this efficiency to the ultimate production of mungbean grains and play a significant role in amino acids formation of the seeds while phosphorus improves the grains capacity and hardness of mungbean seeds. Further it was explained by Mubarak (2005) they reported that nutritional score of mungbean in case of carbohydrates contents it may be increased up to $10-20 \%$. Whereas Gruhun et al. (2000) explained that mungbean grains have much sufficient number of amino acids and other adequate nutritional contents. The results were also in conformity with those of El-Adawy et al. (2003).

\section{Conclusions and Recommendations}

After the current experiment and their analysis of the data it is concluded that legume crops such as mungbean shows a great response towards molybdenum and phosphorus application. Maximum seed yield and yield components such as pods plant ${ }^{-1}$, seeds $\operatorname{pod}^{-1}$, thousand seed weight was observed with addition of molybdenum at rate of $1.5 \mathrm{~kg} \mathrm{ha}^{-1}$ molybdenum and $60 \mathrm{~kg} \mathrm{ha}^{-1}$ phosphorus while all the qualitative attributes such as protein, carbohydrates, seed $\mathrm{N}$ content of mungbean was recorded higher with highest doses of molybdenum and phosphorus. Therefore, it is recommended from the experimental findings that mungbean crop should be grown for higher seed production with a rate of $1.5 \mathrm{~kg} \mathrm{ha}^{-1}$ molybdenum and $60 \mathrm{~kg} \mathrm{ha} \mathrm{k}^{-1}$ phosphorus and performed better than other doses and thus recommended for higher productivity and qualitative attributes in agro climatic condition of study area.

\section{Acknowledgments}

The author all extremely thankful to Almighty Allah for giving us the opportunity and knowledge about the concern field to fulfil the ultimate outcomes of the study. After that all the authors are thankful to the home institution for providing us the platform for the experimental study and lab facilities to complete the concern task.

\section{Novelty Statement}

The main purpose of this study was to enhance the yield, yield components, protein and carbohydrates contents of mungbean crop. This study will play a major role for enhancing yield, protein, carbohydrates and other nutritional status of mungbean crop and will be followed for citations and literature review as well.

\section{Author's Contribution}

Junaid Ahmad: Performed and did overall management of the manuscript.

Shazma Anwar: Designed the experiment.

Anwar Ali Shad and Bibi Amina: Helped in statistical analysis and result and discussion.

Sher Shah Souri: Helped in methodology and lab analysis.

Abidullah: Helped in format of manuscript.

Wajia Noor and Muhammad Adil: Helps in data entry, data analysis and citations.

\section{Conflict of interest}

The authors have declared no conflict of interest.

\section{References}

Abdulla, V.E., 2000. Determination of the residual value of applied phosphorus in some soils of Southern Nigeria. J. Sustain. Agric. Environ., 2(1): 139-143.

Agbede, O.O., 2009. Understanding soil and plant nutrition (1st ed). Salman Press. Nassarawa State, pp. 141-155

Aghatiso, V.O. and T.O. Tayo. 2004. Response of soybean to molybdenum application in Nigeria. Ind. J. Agric. Sci., 64(4): 597-603.

Ahmad, J., F. Ahmad, S. Iqbal, B. Ali, S.M.A. Shah, M. Ali, H. Nawaz, M.W. Abbas and Z. Mahmood. 2018. Response of mungbean yield and yield components into various levels of phosphorous. J. Mater. Sci., 5(1): 1-4. https:// doi.org/10.19080/JOJMS.2018.05.555655

Alam, M.R., M.A. Ali and S.R. Zaman, B. Ahmed and M. Bazzaz. 2010. Effect of phosphorus and boron on the performance of summer mung bean in high Ganges River flood plain soil. J. Agro. Environ., 3(2): 183-186.

Ali, A., A. Amjadi, A. Javed and Y. Muhammad. 2010. Effects of phosphorus in combination with rhizobium inoculation on growth and yield parameters of mung bean. Crop. Environ., 1(1): 53-56.

Ali, M.A., A. Ali, M.I. Ahmed, S.W. Hassan, S.R. Khan and A.A. Abid. 2014. Phosphorus effect on growth and yield parameters on mung bean. Sci. Int., 26(4): 1821-1824. 
Amanullah, R.A. Khattak and S.K. Khalil. 2009. Effects of plant density and $\mathrm{N}$ on phenology and yield of maize. J. Plant Nutr., 32: 245-259. https://doi.org/10.1080/01904160802592714

Anetor, M.O. and E.A. Aknirinde. 2006. Difference in liming potential of some fertilizer material in a tropical acid alfisol. J. Appl. Sci., 6(3): 1686-1691. https://doi.org/10.3923/ jas.2006.1686.1691

Anwar, S., Z.U. Rehman, B. Saeed, M. Islam, M.O. Kham and J. Ahmad. 2018. Response of mung bean to organic sources and nitrogen levels. Pure Appl. Biol., 7(2): 692-699.

AOAC, 1990. Association of Official Analytical Chemists. 1990. Official methods of analysis. (Ed. Helvish, K.) $15^{\text {th }}$ Edn. Avington Vergenia. USA.

Asaduzzaman, 2008. Response of mung bean to nitrogen and irrigation management. Am. Eur. J. Agric. Eniviron. Sci., 3(3): 40-43.

Awomi, T.A., A.K. Singh, M. Kumar and L.J. Borodoli. 2012. Effect of phosphorus, molybdenum and cobalt nutrition on yield and quality of mungbean. Ind. J. Hill. Farm., 25(2): 22-26.

Bhuiyan, M., M. Rahman, F. Afroze, G. Sutradhar, and M. Bhuiyan. 2008. Effect of phosphorus, molybdenum and rhizobium inoculation on growth and nodulation of mungbean. J. Soil Natl., 2(2): 25-30.

Bremmer, J and M. Mulavanne. 1996. Chapter 37 nitrogen total in methods of soil analysis. Part 3. Chemical methods. SSSA Book Series No. 5.

Chatterjee, R. and S. Bandhyopadhyay. 2017. Effect of boron, molybdenum and biofertilizer on growth and yield of cowpea. J. Saud. Soc. Agric. Sci., 16: 332-336. https://doi.org/10.1016/j. jssas.2015.11.001

Chhatrapati, M. and V. Sing. 2017. Effect of zinc and molybdenum on growth, yield attributes, yield and protein in grain on summer blackgram (Vigna mungo). Int. J. Curr. Micro. App. Sci., 7(1): 1-7. https://doi.org/10.20546/ ijcmas.2018.701.140

Choudhary, H.P. and S.K. Das. 2006. Effect of phosphorus and molybdenum application on yield of rainfed black gram and their residual effect on safflower and soil and water conservation in an eroded soil. J. Ind. Soc. Soil. Sci., 44(3): 741-745

Deo, C. and M.L. Kothari. 2002. Effect of modes and levels of molybdenum application on grain yield protein content and nodulation of chickpea grown on loamy sand soil. Commun. Soil Sci. Plant Anal., 33: 2905-2915. https:// doi.org/10.1081/CSS-120014490

El-Adawy, T.A., E.H. Rahma, E.A. Ha, A.A. El-Bedawey and A.E. El-Beltagy. 2003. Nutritional potential and functional properties of germinated mung bean, pea and lentil seeds. Plant Food Hum. Nutr., 58: 1-13. https://doi. org/10.1023/B:QUAL.0000040339.48521.75

Fageria, N.K., L.F. Stones, A.B. Santos. 2015. Molybdenum requirements of dry bean with and without liming. Commun. Soil. Sci. Plant Anal., 46(4): 965-978. https://doi.org/10.1080 /00103624.2015.1018523

FAO/WHO, 1973. Energy and protein requirements. Report of FAO Nutritional Meeting Series No 52. FAO, Rome.

Graham, R.D., and Stangoulis, J.R.S., 2005. Molybdenum and disease. In: Mineral nutrition and plant diseases (eds. L. Dantoff, W. Elmer and D. Huber) St. Paul, MN: APS Press.

Gruhn, P., Goletti, F. and Yudelman, M., 2000. Integrated nutrient management, soil fertility and sustainable agriculture: Current issues and future challenges. International Food Policy Research Institute, Washington DC.

Henry, P.C. and M.F. Smith. 2002. Phosphorus sorption study of selected South African soils. Afr. J. Plant Soil, 19(6): 61-69. https://doi.org/ 10.1080/02571862.2002.10634440

Hi, A. and U. Yovbisere. 2011. Nitrogen and phosphorus requirements of NERICA rice varieties in a savanna Alfisol Nigeria. J. Soil. Environ. Res., 9(2): 20-28.

Hussain, A., A. Ali and I.R. Noorka. 2012. Effect of phosphorus with and without rhizobium inoculation in nitrogen and phosphorus concentration and uptake by Mungbean (Vigna radiata L). J. Agric. Res., 50(1): 49-57.

Iqbal, R.M. and H.Q.I. Chauhan. 2003. Relationship between different growth and yield parameters in maize under varying level of phosphorus. J. Bio. Sci., 3(6): 921-929. https:// doi.org/10.3923/jbs.2003.921.925

Jabbar, B.K.A and H.M. Saud. 2012. Effects of phosphorus on biological nitrogen fixation in soybean under irrigation using saline water. Glob.J. Sci. Front. Res. Agric. Biol., 12(1): 1-10. Jan, M.T., P. Shah, P.A. Hollington, M.J. Khan 
and Q. Sohail. 2009. Agriculture Research Des. Anal. Monograph. Agriculture University Peshawar Pakistan.

Khan, F.U.,A.A. Khan,A.Iqbal,A.Ali,M.Iqbal,M. Alamzeb, M.F. Jan and B. Parmar. 2017. Effect of phosphorus and rhizobium inoculation on yield and yield components of mungbean. J. Pharm. Phytochem., 4(3): 252-258.

Khan, K., and V. Prakash. 2014. Effect of rhizobial inoculation on growth, yield, nutrient and economics of summer urd bean in relation to zinc and molybdenum. Int. J. Adv. Res., 1(1): 1-10.

Kulsum, M.U., M.A. Baqu and M.A. Karim. 2007. Effects of different nitrogen levels on the morphology and yield of black gram. J. Agric., 6: 125-130. https://doi.org/10.3923/ ja.2007.125.130

Kumar, R., Y.V. Singh, S. Singh, A.M. Latare and P.K. Mishra. 2012. Effect of phosphorus and sulphur nutrition on yield attributes, yield of mung bean (Vigna radiata L). J. Chem. Pharm. Res., 4(5): 2571-2573.

Malik, K., S. Kumar and K.P.S. Arya. 2015. Effect of zinc, molybdenum and urea on growth and yield of mungbean. Adv. Res. J. Crop. Impro., 6(1): 59-65. https://doi.org/10.15740/HAS/ ARJCI/6.1/59-65

Meagher, W.R., M. Johnson and P.R. Stout. 1991. Molybdenum requirement of leguminous plants supplied with fixed nitrogen. Plant Physiol., 27(2): 623-629. https://doi.org/10.1104/ pp.27.2.223

Mehboob, M., S. Anwar, J. Ahmad, I. Ullah, I. Nawaz,M.A.Khan,A.M.Ali and J.Akbar.2019. Biofertilizer with phosphorus; a sustainable and eco-friendly approach for enhancing mungbean growth, productivity and protein content in changing climatic scenario. Int. J. Biosci., 15(5): 387-393.

Mubarak, A.E., 2005. Nutritional composition and anti-nutritional factors of mung bean seeds (Phaseolus aureus) as affected by some home traditional processes. Food Chem., 89: 489-495. https://doi.org/10.1016/j. foodchem.2004.01.007

Muhammad, D., A.H. Gurmani and M. Khan. 2005. Effect of phosphorus and rhizobium inoculation on the yield and yield components of mung bean under the rainfed conditions of D.I. Khan. Sarhad J. Agric., 20(4): 575-584.
Naeem, M., S. Ahmed, Z.A. Cheema. 2000. Yield of mung bean as affected by different durations of weed competition under high phosphorus status. Int. J. Agric. Biol., 15(2): 133-135.

Nautiyal, N., S. Singh and C. Chatterjee. 2005. Seed reserves of chickpea in relation to molybdenum supply.J. Sci. Food Agric., 85: 860-864. https:// doi.org/10.1002/jsfa.1929

Nikfarjam, S.G. and H. Aminpanah. 2015. Effect of phosphorus fertilization and pseudomonas fluoresces strains on the growth and yield of faba bean (Vicia faba). Agric. Res., 33(4): 15-21. https://doi.org/10.4067/S071834292015000400003

Osadeke, V.E., 2005. Determination of Phosphorus requirements of Cowpea (Vigna unguiculata) in the acid soils of Southeastern Nigeria using sorption Isotherms. Glob. J. Agric., 4(2): 135138. https://doi.org/10.4314/gjass.v4i2.2262

Padhi, P.P. and S.K. Pattanayak. 2018. Effect of lime coating and molybdenum seed treatment on nodulation, growth and yield of different pulses. Int. J. Curr. Microbiol. App. Sci., 7(2): 1417-1426. https://doi.org/10.20546/ ijcmas.2018.702.171

Paricha, P.C., N.C. Sahoo and M. Kar. 2008. Significance of molybdenum and applied nitrogen on the chemical composition and seed yield of green gram. Ind. J. Plant. Physiol., 26(6): 305-313.

Pattanayak, S.K., D. Das, M.R. Jena and R.K. Nayak. 2000. Seed treatment of green gram with molybdenum and cobalt: Effect on nodulation, bio-mass production on $\mathrm{N}$ uptake in an acid soil. J. Ind. Soc. Soil. Sci., 48: 769-773.

Raboy, V., 2003. Molecules of interest myoinositol-1, 2, 3, 4, 5, 6-hexakisphasphate. Photochemistry, 64: 1033-1043. https://doi. org/10.1016/S0031-9422(03)00446-1

Rahman, M.M., M.M.H. Bhuiyan, G.N.C. Sutradhar, M.M. Rahman and A.K. Paul. 2008. Effect of phosphorus, molybdenum and rhizobium inoculation on yield and yield attributes of mung bean. Int. J. Sus. Crop. Prod., 3(6): 26-33.

Rani, M., P. Ved and K. Khalil. 2016. Response of mung bean to phosphorus, Sulphur and PSB during summer season. Agric. Sci. Digest., 36(2): 146-148. https://doi.org/10.18805/asd. v36i2.10637

Ryan, J., H. Ibrikci, A. Delgado, J. Torrent, R. 
Sommer and A. Rashid. 2012. Significance of phosphorus for agriculture and the environment in the West Asia and North Africa region. Adv. Agro., 114(4): 91-153. https://doi.org/10.1016/ B978-0-12-394275-3.00004-3

Sawan, Z.M., S.A. Hafez, A.E. Basyony. 2001. Effect of phosphorus fertilization and foliar application of chelated zinc and calciumon seed, protein and oil properties of cotton. J. Agric. Sci., 13(6): 191-198. https://doi.org/10.1017/ S0021859601008644

Schulze, J., G. Temple, S.G. Temple, H. Beschow and C.P. Vance. 2006. Nitrogen fixation by white lupin under phosphorus deficiency. Annals Bot., 98(6): 731-740. https://doi.org/10.1093/ $\mathrm{aob} / \mathrm{mcl} 154$

Singh, B. and R.G. Pareek. 2003. Effect of phosphorus and biofertilizer on growth and yield of mungbean. Ind. J. Pulses Res., 16: 3133.

Singh, S.S., M.A. Khan and A. Srivastava. 2014. Effect of boron and molybdenum application on seed yield of mungbean. Asian J. Biol. Sci., 9(2): 169-172. https://doi.org/10.15740/HAS/
AJBS/9.2/169-172

Tahir, M., A. Sher, M.A. Majeed. 2014. Effect of Mo on yield and quality of black gram. Pak. J. Life Soc. Sci., 12(2): 101-105.

Tariq, S., S. Ali and S.S. Ijaz. 2007. Improving nitrogen fixation capacity and yield of mung bean and mash bean by phosphorus management in Pothowar. Sarhad J. Agric., 23(4): 1027-1032.

Velu, G. and P. Savithri. 2008. Molybdenum requirement for enhancing the yield of black gram and green gram. Madras. Agric. J., 70(4): 629-630.

Warren, G.P., 2002. Fertilizer phosphorus sorption and residual values in tropical African soils. NR Bull., pp. 37.

Williams, R.J.P. and J.J.R. Silva. 2002. The involvement of molybdenum in life. Biochem. Biophys. Res. Commun., 29: 293-299. https:// doi.org/10.1006/bbrc.2002.6518

Yadav, V.K. and P. Singh. 2017. MSc. thesis. Department of Agri Chem and Soil Sci. Rajhastan College of Agriculture. 